\begin{tabular}{c} 
Volume and Issues Obtainable at Center for Sustainability Research and Consultancy \\
Journal of Accounting and Finance in Emerging Economies \\
ISSN: 2519-0318 ISSN (E) 2518-8488 \\
Volume 2: Issue 1 June 2016 \\
JSRᄃ \\
Journal homepage: www.publishing.globalcsrc.org/jafee \\
\hline
\end{tabular}

\title{
Information Content of Earnings Managements: Implications on Growth and Value Companies
}

\author{
${ }^{1}$ Windu Mulyasari, ${ }^{2}$ Slamet Sugiri, ${ }^{3}$ Heyvon Herdhayinta \\ ${ }^{1 *}$ Fakultas Ekonomi dan Bisnis, Universitas Sultan AgengTirtayasa, Indonesia, windu.nryd@ gmail.com \\ ${ }^{2}$ Fakultas Ekonomika dan Bisnis, Universitas Gadjah Mada, Yogyakarta, ssugiri@feb.ugm.ac.id \\ ${ }^{3}$ Fakultas Ekonomika dan Bisnis, Universitas Gadjah Mada, Yogyakarta, heyvonh@ugm.ac.id
}

\begin{tabular}{l}
\hline ARTICLE DETAILS \\
\hline History \\
Revised Format May 2016 \\
Available Online June 2016 \\
\end{tabular}

\section{Keywords}

Earnings Management

Growth and Value Firm

Incremental Information

JEL Classification:

O43, O49, D46, D49

\begin{abstract}
Objective: The purpose of this study is to investigate the pattern of earnings management on growth and value companies in Indonesia. This study predicts that earnings management has information contents. Therefore, earnings management tends to degrade the quality of earnings, then affect the future profitability. This study analyzes the effect of earnings management information content to the company's future profitability. This study provides an understanding about accounting information at certain market price levels for growth and value companies.

Findings: Findings of this study indicate the differences between earnings management influence on growth and value companies. The results also support the differences of relative incremental information content of earnings management on growth and value companies. The growth firms tend to do earnings management and have higher profitability compared to the value firms. The implication is that the incremental information content of earnings management on growth firms is lower than those of the value firms to predict future profitability.

Implication: The contribution of this research is to provide an in-depth review on earnings management study associated with company life cycle (growth and value), as well as to give additional understanding about the existence of incremental information content of earnings management. Thus, firms show different earnings management behaviors and ultimately those behaviors affect the quality of profit to predict future earnings.
\end{abstract}

(C) 2016 The authors, under a Creative Commons AttributionNonCommercial 4.0

Corresponding author's email address: windu.nryd@ gmail.com

Recommended citation: Mulyasari, W., Sugiri, S. and Herdhayinta, H. (2016). Information content of earnings managements: Implications on growth and value companies. Journal of Accounting and Finance in Emerging Economies, 2 (1) 47- 56. DOI: https://doi.org/10.26710/jafee.v2i1.73 


\section{Introduction}

The purpose of this study is to investigate the pattern of earnings management in growth and value companies in Indonesia. Earnings management has information contents and tends to degrade the quality of earnings. This study analyzes the effect of earnings management on company profitability. Kallunki and Martikainen (2009) find that earnings management can be used to predict future profitability. Earnings management can mislead investors and influence decision-making process. However, there is still much debate on the pattern differences of earnings management in each country. Shubita and Shubita (2010) indicate that earnings management has no effect of on future profitability. Both studies examine the incremental information content of earnings management. Differences in previous research evidences create a gap within this study.

The pattern of earnings management in a company can be influenced by the company life cycle. Gray (1988) reports that culture affects the values of accounting system and accounting practice. Basuki et al. (2010) observe that countries with high power distance and low individualism or high collectivism have lower earnings quality. Leuz et al. (2003) and Francis and Wang (2008) find that countries with low level of investor protection have low level of earnings quality. De Fond and Hung (2007) and Hung (2000) prove that investor protection is positively correlated with the value relevance of accounting information. The researches support the notion that patterns of earnings management is different for each country. The pattern of earnings management is also different for types of company according to their life cycle.

This research is conducted on public companies in Indonesia with characteristics of high power distance and high collectivism that can affect the behavior of professionalism and transparency in accounting practices (Basuki et al., 2010). The implication is that public company in Indonesia is likely to report low level of earnings quality. Research on the incremental information content of earnings management has been conducted by Subhita and Subhita (2010) in Jordan. Indonesia has different culture compared to Jordan, in which Indonesia has low earnings quality. The research question of this study is whether all publicly traded companies in Indonesia have the same character in earnings management. Is there any difference in earnings management behaviors? Therefore, this study explores earnings management behavior that may be different for every public company in Indonesia.

Public companies as the sample of this study are grouped according to their life cycle. This study attempts to examine factors as the basis of differences in earnings management pattern. According to Madhogarhia et al. (2009), earnings management shows different behaviors on growth and value companies. Another study by Yan (2006) finds that firm size is growing along with its life cycle. Earnings management in growth firms is more aggressive than in any other life cycle stages. The focus of this study is to explore the implications of earnings management on growth and value firms in Indonesia. The growth firms have low profit or high market to book ratio. On the other hand, value firms are companies with high level of profit or low market to book ratio. Thus, a statement that Indonesia tends to have lower earnings quality should be examined by reviewing whether the company is a growth or value firm. Value firms are "glamour", in which investors are confidence. Investors tend to believe in financial statements, and investment decision is based on company reputation. Investor confidence in growth firms is weak and investors still need to analyze financial statements to create investment decisions. This study provides deeper understanding that public companies in Indonesia generally tend to have low earnings quality due to the low investor protection as well as high power distance.

The contribution of this study is to provide in-depth study on earnings management related to company life cycle (growth and value), as well as to provide additional understanding of the existence of additional information content of earnings management. Thus, in a different life cycle, the company has 
a different pattern of earnings management. The implication may affect the quality of profits to predict future profitability.

\section{Literature Review}

Healy and Wahlen (1999) examine the aspects contained in earnings management. The first, intervention of earnings management on financial reporting can be done by using judgment, for instance judgments in estimating future economic events, such as estimations of economic life and residual values of fixed assets, pensions, deferred tax, loss on receivables and impairment. Managers also have choices of accounting method, such as depreciation and cost methods. Second, earnings management can mislead the stakeholders about firm's economic performance because management has information access that is not accessible for outsiders.

Accounting literature defines two perspectives of earnings management, namely opportunistic perspective and information perspective (Holtausen, 1990). Information perspective means that decisions on accounting choice indicate the expectation of company future performance. Meanwhile, according to opportunism perspective, managers manage earnings to get incentives transferring stakeholders' wealth for their self-interests. There are various motivations encouraging profit management. Positive accounting theory proposes three motivations of earnings management: (1) the bonus plan hypothesis, (2) the debt hypothesis, and (3) the political cost hypothesis (Watts and Zimmerman, 1986).

Empirical evidences indicate that large companies tend to choose accounting methods that reduce profits (usually based on political cost hypothesis), companies facing debt covenant tend to choose accounting methods to increase profits (usually based on the debt hypothesis), and managers working at companies with bonus scheme will choose accounting methods that can increase profits (usually based on bonusplan hypothesis) (Watts and Zimmerman 1986, 1990). McNichols and Wilson (1988) add the fourth factor encouraging managers to affect financial achievement, namely the operating, investing, and financing policies.

\subsection{Relationship between Earnings Management and Growth and Value Companies}

Growth firms are companies with low profit or high market to book ratio. Meanwhile, value firms are companies with high profit or low market to book ratio. The stocks of growth and value companies are determined by the ratio of profit dimension such as market-to-book ratio. Fama and French (1992); Arshanapalli et al (1998); and Capaul et al. (1993) find that in the long run, value stocks outperform growth stocks in the US and overseas markets. Fama and French (1995); and Chen and Zhang (1998) show that companies with high book to market (B/M) ratio have lower profitability, higher financial leverage, and higher earnings uncertainty.

Stock price of growth firms falls when company reports low profits. Information asymmetry leads to earnings management. Growth firms have bigger incentive to manage earnings compared to value firms. Accruals discretionary as an indicator of earnings management would be higher for growth firms rather than value firms. Lakonishok et al. (1994) argue that investor expectations are based on calculations of past performance. Naive investors that are too optimistic about the prospect of glamour stocks tend to over trust the stocks. Therefore, they eventually increase the stock price (overpriced stock). If their expectations are not met, the stocks end up being a loss. According to DeBont and Thaler (1987), profit dissatisfaction adversely affects the market price of growth stock than value stock.

Skinner and Sloan (2002) argue that disproportionate response on negative earnings surprise explains different returns between growth and value stocks. Stock price of growth firms will experience significant negative adjustment when the firms report earnings surprise. Therefore, growth firms tend to do earnings management compared to value firms. 
H1: Earnings management in growth firms is lower than earnings management in value firms.

\subsection{Incremental Information Content of Earnings Management}

Previous researches find that earnings management is conducted to obtain positive earnings, to maintain sustainable performance, and to meet analysts' forecasts. Myers et al (2007) argue that firms manage earnings to show growth firm consistency. The firms report increasing profit continuously so that profits remain high. Furthermore, Kallunki and Martikainen (2003) prove that earnings management may affect the quality of earnings information, and ultimately reduce the quality of financial analysis based on earnings figure. Earnings management can be done by adjusting higher profit when the company experiences difficulties and lower profit when company is in a good condition (Subhita and Subhita, 2010). According to Subramanyam (1996) and Ali et al (2000), discretionary accruals improve the ability to predict future earnings. Ali et al (2000) examine the relationship between accruals and future returns of naive investors. The findings show that the ability of accruals to predict future profitability does not work when market participants are unable to understand the relevant valuable information. Kallunki and Martikainen (2003) describe that earnings management is significantly related to future profitability.

H2: $\quad$ Current profitability affects future profitability.

H3: Incremental information content of earnings management affects current profitability in predicting future profitability

Patel, Prasad, and Naidu (2009) examine the pattern of earnings management between private and stateowned companies. This study refers to company life cycle to distinguish the patterns of earnings management. Logically, growth firms are trying to manage earnings in order to attract investors. Meanwhile, glamorous companies manage earnings to increase reputation and attract more investors.

H4: Growth firm's profitability is lower than value firm's profitability.

H5: Incremental information content of earnings management in growth firms is lower than in value firms.

\section{Research methods}

\subsection{Sampling Design}

The samples of this research are public companies in Indonesia from 2010 - 2012. The public companies are listed in Indonesia Stock Exchange during that period and report annual financial statement.

\subsection{Research Procedure}

Growth and value firms are categorized based on several factors: 1$)$ market to book $(\mathrm{m} / \mathrm{b})$ ratio; 2) price to earnings (p/e) ratio; 3) price to cash flow (p/cf) ratio; 4) earnings per share growth; and 5) sales growth. Companies are ranked based on geometric mean variable for each year. Growth firms are those in top $25 \%$ of the geometric mean and value firms are those in the bottom $25 \%$ of the geometric mean. Modified time-series model from Jones (1991) is used in this research. Jones model divides reported total accruals into nondiscretionary (expected) and discretionary (unexpected) components. Accrual nondiscretionary is derived from economic variable such as sales and investment level of fixed assets. Accrual discretionary is not described by economic variable but as a result of management decision. Accrual discretionary is used as a proxy of earnings management. Total accrual regression equation is presented in Equation 1.

TAit/Ait-1 $=\alpha 1[1 /$ Ait-1] $+\alpha 2[\Delta$ REVit/ Ait-1] $+\alpha 3[$ PPEit/ Ait-1] + cit....................... $)$

TAit $=$ total accruals in year $\mathrm{t}$ for firm $\mathrm{i}$ (the difference between net income and cash flow from operating activities);

$\triangle$ REVit $\quad=$ revenues in year $\mathrm{t}$ minus revenues in year $\mathrm{t}-1$ for firm $\mathrm{i}$;

PPEit = gross property, plant and equipment in year $\mathrm{t}$ for firm $\mathrm{i}$; 
Ait-1 = total assets in year $\mathrm{t}-1$ for firm $\mathrm{i}$;

cit $\quad=$ error in year $\mathrm{t}$ for firm $\mathrm{i}$;

$\alpha 1, \alpha 2$ and $\alpha 3=$ Model Coefficients.

$\mathrm{i} \quad=1, \ldots, \mathrm{N}$

$\mathrm{t} \quad=1, \ldots, \mathrm{ti}$, year index for the years included in the estimation period for firm $\mathrm{i}$.

Total accrual (TA) is defined as the difference between net income (NI) and cash flow from operating activities (OCF):

$\mathrm{TA}=\mathrm{NI}-\mathrm{OCF}$.

T-test is conducted to test hypothesis 1 whether the growth firms more aggressively manage their earnings. Hypothesis 2 states the current profitability effect on future profitability. The regression equation is presented in equation 3.

PROFITit $=\alpha 0+\alpha 1$ PROFITit $-1+\alpha 2$ ASSETit $+\varepsilon i t$

PROFITit = profitability in year $\mathrm{t}$ for firm $\mathrm{i}$

PROFITit-1 = profitability in year $\mathrm{t}-1$ for firm $\mathrm{i}$

ASSETit $\quad=$ total asset in year $\mathrm{t}$ for firm $\mathrm{i}$

The objective of the equation is to predict whether current profitability (PROFITit-1) can predict future profitability (PROFITit). Total assets (ASETit) is a control variable used in equation 4. Hypothesis 3 is tested using regression equation 4.

PROFITit $=\square 0+\square$ 1PROFITit-1 $+\square$ 2ADit-1 $+\square$ 3ASSETit + eit.

ADit-1 = earning management in year $\mathrm{t}-1$ for firm 1

Hypothesis 4 predicts the differences on profitability of growth and value firms using Mann Whitney Utest. Hypothesis 5 states that the incremental information content of earnings management in growth firms will be lower than that in value firms. To test this hypothesis, the regression equation is presented in equation 5 .

PROFIT_it $=\gamma_{-} 0+\llbracket \gamma_{-} 1$ PROFIT $\rrbracket \_(i t-1) \llbracket+\gamma_{-} 3$ AD_(it- 1$)+\gamma_{-} 4$ TIPE $\rrbracket \_$it $\left(+\varepsilon \rrbracket \_\right.$it

TIPE: Dummy variable for growth (0) and value (1) firm

The coefficients obtained from the regression test are $\square 0, \square 1, \square 2, \square 3$, and $\square 4$. They are inserted back into the equation to obtain the expected profitability. The new equation is presented in Equation 6.

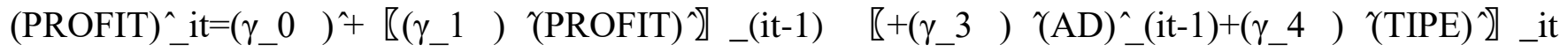
$\left.\left[+\varepsilon^{\wedge}\right)\right]$ it

The next test using Mann Whitney U-test is conducted on the expected profitability of the growth and value firms.

\section{Data analysis}

Total samples analyzed in this study are 1135 public companies listed in Indonesia Stock Exchange for 2010-2012. Companies are categorized based on five measurement criteria namely: market-to-book (M / $\mathrm{B})$ ratio; price to earnings ( $\mathrm{P} / \mathrm{E})$ ratio; price to cash flow (P / CF) ratio; earnings per share growth; and sales growth. Companies in the top $25 \%$ are classified as the value firms and companies in the bottom $25 \%$ are the growth firms.

Hypothesis 1

Hypothesis 1 stated that there is a difference between earnings management in growth and value firms. 
The t-test results can be seen in Table 2 .

Table 2: Results of earnings management in growth and value firms

\begin{tabular}{l|l|r}
\hline \multirow{2}{*}{ Mean } & Growth & 9,2126 \\
& Value & 9,5980 \\
\hline Lavene's test for equality of & F & 0,536 \\
variances & Sig. & 0,465 \\
\hline \multirow{2}{*}{ t-test for equality of mean } & T & $-4,4665$ \\
& Mean difference & $-0,3854$ \\
& Sig. & 0,000 \\
\hline
\end{tabular}

The result shows that the mean of earnings management in group growth firms (9.2126) is less than the value firms (9.5980). Variability in test results obtained Lavene's F test of $0.536(0.465)$. Level of statistical significance of $>0.05$ means that the two groups of observations are not too different. The mean equality of earnings management in the t-test obtained negative $t(-4.4665)$ and the mean difference is negative $(-0.38547)$ at the level of statistical significance 0.00 . The conclusion is that the mean of earnings management in growth firm is lower than value firm. The results do not confirm the hypothesis 1 which states that growth firms tend to do earnings management more than value firms. In fact, the value firms tend to perform earnings management more than the growth firms. Hypothesis 1 is not supported because the company faces high political costs to manage earnings to be low or have a high debt to manage earnings to be high.

Hypothesis 2

Hypothesis 2 states that firm current profitability can predict future profitability. Linear regression is conducted and the results are shown in Table 3 .

Table 3: Results of regression equation 4

\begin{tabular}{lcc}
\hline & & Prob. \\
\hline $\mathrm{F}$ & 154,434 & 0,000 \\
ADJ R $^{2}$ & 0,214 & \\
\hline Model & $\mathrm{B}$ & Prob. \\
\hline Constant & $-15,261$ & 0,016 \\
PROFIT $_{\text {it-1 }}$ & 0,431 & 0,000 \\
LASET $_{\text {it }}$ & 2,243 & 0,001 \\
\hline
\end{tabular}

The results shows the value of $\mathrm{F}$ statistic 154.434 ( $\mathrm{p}$-val $=0.000$ ). This confirms that the model could explain the research purpose. The value of adjusted $\mathrm{R} 2$ of 0.214 means that the independent variables used in the equation explains the dependent variable at $21.4 \%$. The rest is explained by other variables. Furthermore, coefficient variables is statistically significance at level $<\alpha(0.05)$. Coefficient of PROFITit-1 is $0.431(0.000)$ and LASSETit is $2,243(0,001)$. The results confirm the hypothesis that current profitability affects future profitability.

Hypothesis 3

Hypothesis 3 states that there is incremental information content of earnings management on current 
profitability when current profitability is used to predict future profitability. Equation 5 is basically testing the information content of earnings management on current profitability when used to predict future profitability. Table 4 shows the results of regression equation 5 .

Table 4: Results of regression equation 5

\begin{tabular}{lcc}
\hline & & Prob. \\
\hline F & 88,475 & 0,000 \\
\hline Model & 0,579 & \\
\hline Constant & $\mathrm{B}$ & Prob. \\
PROFIT $_{\text {it-1 }}$ & $-1,244$ & 0,032 \\
AD $_{\text {it-1 }}$ & 0,673 & 0,000 \\
ASSET $_{\text {it }}$ & $-0,025$ & 0,667 \\
\hline
\end{tabular}

The results of regression equation 5 shows the value $F$ statistic 88.475 ( $p$-val = 0.000 ). The value confirms that the model can be used. The value of adjusted R2 of 0.579 means that the independent variables used in the equation explains $57.9 \%$ of the dependent variable. Furthermore, coefficient variable of earnings management is not statistically significant -0.025 (0.667). When incremental information content of earnings management is low (high), the effect of current profitability when it is used to predict future profitability is high (low). Coefficients of current profitability is $0.673(0.000)$ and coefficients of total assets is 0.175 (0.036). The results do not support the hypothesis that current profitability affects future profitability. It shows conflicting evidence compared to Kallunki and Martikainen (2003) which states that earnings management can predict future profitability. However, this finding confirms Shubita and Shubita (2010), that earnings management does not affect future profitability.

Hypothesis 4

Hypothesis 4 states that the profitability of growth firms is lower than of the value firms. Mann Whitney U-test is conducted and the results are shown in Table 5.

Table 5: Results of Mann Whitney U-test

\begin{tabular}{lcccc}
\hline & Mean Rank & Mann Whitney & Z & P-value \\
\hline Growth & 375,08 & 63026,5 & $-8,024$ & 0,000 \\
Value & 512,98 & & & \\
\hline
\end{tabular}

The test shows the mean rank among growth firms (375.08) is lower than the value firms (512.98). These differences are explained further with negative $\mathrm{Z}$ value $(-8.024$, $\mathrm{p}$-val $=0.000)$, which means that the mean of growth firms is lower than the value firms. The conclusion is that the profitability of growth firms is lower than the profitability of the value firms. The result confirms hypothesis 4 .

Hypothesis 5

Hypothesis 5 states that the incremental information content of earnings management in growth firms will be lower than the value firms to predict future profitability. In hypothesis testing, coefficient 
regression model 5 is used $\left(\gamma_{0}, \gamma_{1}, \gamma_{2}, \gamma_{3}, \gamma_{4}\right)$ to predict the expected profitability (see equation 6). The results can be seen in Table 6.

Table 6: Results of equation 6

\begin{tabular}{lcl}
\hline & & Prob. \\
\hline $\mathrm{F}$ & 51,589 & 0,000 \\
ADJ R & 0,386 & \\
\hline Model & $\mathrm{B}$ & Prob. \\
\hline CONST (prob) & 12,904 & 0,265 \\
PROFIT $_{\text {it-1 }}$ & 0,461 & 0,000 \\
AD $_{\text {it }}$ & $-1,242$ & 0,322 \\
TIPE & 6,422 & 0,000 \\
\hline
\end{tabular}

Results shows that current earnings management (ADit-1) does not affect the future profitability of the company (PROFITit) $(0.461$, p-val $=0.032)$. Current Profitability (PROFITit-1) affects the future profitability (PROFITit) to $0.461(0.000)$. Furthermore, the coefficient is included in the equation 5 to obtain expected profitability (see equation 6).

$(\mathrm{PROFIT})^{\wedge} \_\mathrm{it}=12,904+\llbracket\left(0,461 \mathrm{PROFIT} \rrbracket \_(\mathrm{it}-1) \quad \llbracket-1,242 \mathrm{AD} \_(\mathrm{it}-1)+6,422(\mathrm{TIPE})\right)^{\wedge} \_$it $\llbracket+\varepsilon \rrbracket \_$it 6)

The expected profitability then is used to test the difference between growth firms and value firms. Mann Whitney U-test is conducted to test the difference between the expected profitability of the growth and value firms. Results can be seen in Table 7.

Table 7: Results of Mann Whitney U-test

Mean Rank $\quad$ Mann $\quad$ P $\quad$ Palue

Whitney

\begin{tabular}{llccc}
\hline Growth & 623,50 & 114691 & $-7,143$ & 0,000 \\
Value & 480,98 & & & \\
\hline
\end{tabular}

Mean of the expected profitability from the value firms is less (480.98) than the growth firms (623.40). $\mathrm{Z}$ values $(-7.143$; $\mathrm{p}$-val $=0.000)$ shows that means of the value firms is less than the growth firms. The incremental information content of value firms is lower to predict future profitability than the growth firms. The results do not confirm the hypothesis 5 . The conclusion is that there is a difference between the incremental information content of growth firms and value firms.

Value firms tend to perform earnings management compared to growth firms. The profitability of value firms is also higher than that of the growth firms. However, the incremental information content on earnings management in value firms is lower than the growth firms. Therefore, the conclusion is that value firms in Indonesia tend to perform earnings management and have higher level of profitability than the growth firms. This might happen because the value firms are reputable and try to make better financial reports for investors. Based on the political cost hypothesis, large companies tend to choose accounting methods that reduce profits. Value firms are companies with high profits or low market to book ratio. Thus, companies are trying to decrease profits due to the possibility of higher political costs. If the value firms are in high debt, there is the possibility of the firms trying to choose the accounting method that can reduce profits as emphasized the debt hypothesis. 


\section{Conclusion and discussion}

Company and management interests lead to earnings management. Earnings management can affects overall company performance report. This study addresses relative incremental information content of earnings management, which can affect company profitability. The aim of this study is to investigate the differences of relative incremental information content of earnings management. This study compares two types of firms based on company life cycle namely growth and value companies. Previous studies indicate that public companies in Indonesia generally perform earning management, so that earnings quality is generally low. This study provides deeper understanding about earnings management and contributes in examining the type of companies (growth and value) in performing earnings management in Indonesia.

The findings of this study prove that the value firms tend to perform earnings management to improve the company's profitability. The conclusion is supported by statistical evidence about the differences between earnings management in growth and value firms. The results also indicate that growth firms tend to perform earnings management compared to the value firms. Tests on companies' profitability also show differences between growth and value firms. Growth firms tend to have lower profitability levels than the value firms. Findings on incremental information content on earnings management when current profitability used to predict future profitability indicate that those of the value firms tend to be lower than those of the growth firms. Based on political cost hypothesis, large firms tend to choose accounting methods that reduce profits. Value firms are companies with high profits or low market to book ratio. Thus, companies are trying to reduce profits due to the possibility of higher political costs. Based on debt hypothesis, if the value firms are in high debt, there is a possibility of the firms trying to choose accounting method to lower profits.

This research has limitations, such as sorting company's growth and value based on ranking of geometric mean of 5 variables observation and taking the top $25 \%$ as value firms and the bottom $25 \%$ as growth firms. Determination of the geometric mean rank is constrained because many companies do not report complete financial statements, and therefore cannot be included in the sample. Future studies suppose to study deeper determination of growth and value companies.

Another limitation is to determine the proxy of company profitability. The proxy used in this study is profit margins. The use of a single proxy bias is unlikely to capture the general purpose of research to study the effect of earnings management on company performance. Suggestion for further research is to use a composite factor with some proxy of profitability.

Future researches also need to examine deeper the incremental information content of earnings management since earnings management affects the overall financial performance. Deeper studies can determine the right proxy of incremental information content of earnings management that is expected to reveal the earnings management behavior.

\section{References}

Ayres, F. L. (March 1994). "Perception of Earnings Quality: What Managers Need toKnow". Management Accounting, page: 27-29.

Arshanapalli, B., Coggin, T. D. and Doukas, J. (1998), Multifactor asset pricing analysis of international value investment strategies, Journal of Portfolio Management, 24, 10-23.

Basuki, H., Y. Nurim, dan F.R.R. Anggraini. 2010. The Effect of Culture in Family Firms' Earnings Quality: An Examination Alignment VersusEntrechment Approach in Agency Theory. Working Paper.UniversitasGadjahMada Jogjakarta.

Cahan, S. F. (1992). "The Effects of Antitrust Investigations on Discretionary Accruals:A Refined Test of Political-Cost Hypothesis”. The Accounting Review, 67 (1): 77-95. 
Capaul, C., Rowley, I. and Sharpe, W. (1993), International value and growth stock returns, Financial Analysts Journal, 49, 27-36.

Carlson, Steven J., danChenchuramaiah T. Bathala. (1997), Ownership Differences and Firms Income Smoothing Behavior.Journal of Business and Accounting, 24 (2).

Fama, E. F. and French, K. R. (1992), The cross-section of expected stock returns, Journal of Finance, 47, 427-65.

Fama, E. F. and French, K. R. (1995), Size and bookto-market factors in earnings and returns, Journal of Finance, 50, 131-55.

Gujarathi, M.R. and Hoskin, R.E. (December 1992). "Evidence of Earnings Management by The Early Adopters of SFAS 96". Accounting Horizon, page: 18-31.

Gray, S.J. 1988. Towards a Theory of Cultural Influence on the Development of AccountingSystems Internationally.ABACUS 24(1): 1-15.

Hair, Joseph E., Anderson, Rolph E., Tatham, Ronald L., Black, William C., 2010, "Multivariate Data Analysis", Prentice-Hall International Inc.

Healy, P. M. (1985), The effect of bonus schemes on accounting decisions, Journal of Accounting and Economics, 7, 85-107.

Healy, Paul, and James Wahlen.(1999), A Review Of The Earnings Management Literature and ItsImplications For Standard Setting. Accounting Horizons, Vol. 13, No.4, PP 365-383

Hung, M. 2000. Accounting Standards and Value Relevance of Financial Statements: AnInternational Analysis. Journal of Accounting and Economics, 30: 401-420.

Holthausen, R. W. (1990), Accounting method choice: opportunistic behavior, efficient contracting and information perspectives, Journal of Accounting and Economics, 12, 207-18.

Kallunki, J. P. and Martikainen, M. (2003), Earnings management as a predictor of future profitability of Finnish firms, European Accounting Review, 12, 311-25.

Lakonishok, J., Shleifer, A. and Vishny, R. (1994), Contrarian investment, extrapolation, and risk, Journal of Finance, 49, 1541-78.

LaPorta, F. Lopez-De-Silanes, A. Shleifer, dan R. Vishny. 1998. Law and Finance. Journalof Political Economy Vol. 106: 1113-1155.

Lev, B. (1989). "On The Usefulness of Earnings and Earnings Research: Lessons and Directions from Two Decades of Empirical Research". Journal of Accounting Research, 27 (2): 153-192.

Leuz, C, D, Nanda, and P. Wysocki.(2003). Barnings Management Aiid Investor Protectitin:An International Comparison. Journal of Financial Economics, 69 (3): 505-27.

Madhogarhia, Pawan, Sutton, Ninon K., and Kohers, Theodor. (2009)."Earnings Management PracticesAmong Growth and Value Firms”.Applied Financial Economics, 19, 1767-1778

Magnan, M. and Cormier, D. (1997). "The Impact of Forward-Looking Financial Data in IPOs on the Quality of Financial Reporting".Journal of Financial Statement Analysis, page: 6-17.

Myers, J. N., Myers, L. A. and Skinner, D. J. (2007), Earnings momentum and earnings management, Journal of Accounting, Auditing and Finance, 22, 249-84.

Skinner, D. J. and Sloan, R. G. (2002), Earnings surprises, growth expectations, and stock returns or don't let an earnings torpedo sink your portfolio, Review of Accounting Studies, 7, 289-312.

Subramanyam, K. R. (1996), The pricing of discretionary accruals, Journal of Accounting and Economics, 22, 249-81.

Shubita, MoadeFawzi and Shubita, Mohammad Fawzi. (2010), The Incremental Information Content of Earnings Management, International Research Journal of Financ and Economics, 48.

Watts, R. and Zimmerman, J. (1986), Positive Accounting Theory, Prentice-Hall, Englewood Cliffs, NJ.

Watts, R, L., and Zimmerman, J, L. (1990). "Positive Accounting Theory: A Ten YearPerspective". The Accounting Review, 60 (1): 131-156.

Xiong, Yan, 2006, Earning management: A theoretical perspective. The Journal of AmericanAcademy of Business, Vol. 9, No. 1, PP 214-219 